\title{
Antecedents, Moderators and Outcomes of Brand Image: A Conceptual Framework
}

\author{
Wasib B Latif1 \\ Md. Aminul Islam² \\ Nahid Farzana ${ }^{3}$ \\ Md. Mahedi Hasan ${ }^{4}$ \\ Eman Hossain ${ }^{5}$ \\ Md. Nazrul Islam 6 \\ Jannatul Ferdous ${ }^{7}$ \\ Md. Yeasir Arafat Bhuiyan ${ }^{8}$ \\ Md. Monir Hossain 9
}

${ }^{1} \mathrm{PhD}$. Candidate, School of Business Innovation and Technopreneurship, Universiti Malaysia Perlis,

01000 Kangar, Perlis, Malaysia, Email: wasibibaru@gmail.com

${ }^{2}$ Associate professor, School of Business Innovation and Technopreneurship,

Universiti Malaysia Perlis, 01000 Kangar, Perlis, Malaysia.

${ }^{3}$ Assistant Professor, Department of Business Administration, Prime University, 2A/1, North East of Darus Salam Road, Mirpur, Section-1, Dhaka 1216, Bangladesh.

${ }^{4}$ Assistant Professor, Department of Business Administration, Prime University, 2A/1, North East of Darus Salam Road, Mirpur, Section-1, Dhaka 1216, Bangladesh. ${ }^{5}$ Assistant Professor, Department of Business Administration, Prime University, 2A/1, North East of Darus Salam Road, Mirpur, Section-1, Dhaka 1216, Bangladesh.

${ }^{6}$ Senior Lecturer, Department of Business Administration, Prime University, 2A/1, North East of Darus Salam Road, Mirpur, Section-1, Dhaka 1216, Bangladesh.

${ }^{7}$ Senior Lecturer, Department of Business Administration, Prime University, 2A/1, North East of Darus Salam Road, Mirpur, Section-1, Dhaka 1216, Bangladesh.

${ }^{8}$ Senior Lecturer, Department of Business Administration, Prime University, 2A/1, North East of Darus Salam Road, Mirpur, Section-1, Dhaka 1216, Bangladesh.

'Lecturer, Department of Business Administration, Prime University, 2A/1, North East of Darus Salam Road, Mirpur, Section-1, Dhaka 1216, Bangladesh.

Doi:10.5901/mjss.2014.v5n23p221

\section{Abstract}

The conceptual framework of brand image is a combination of antecedents, moderators and outcomes that create differential effects on customer response to the marketing of the brand. By constructing a conceptual framework of brand image, organizations will build a competitive advantage in the marketplace that will increase their overall image with long-term sustainability. Indeed, recent trends in modern marketing have changed tremendously, and study of conceptual framework of brand image is increasingly becoming considerable to keep pace with this change. In this conceptual paper, we have summarized the literatures on currently prevailing concepts and approaches on brand image that will allow us to identify the conceptual framework of brand image, and therefore will facilitate organizations to enhance their marketing efficiency and effectiveness. In this framework, we discussed a case study in Bangladesh, and in light of the findings of this case study we put forward the notion that the conceptual framework of brand image need to be associated with organizational activities.

Keywords: Brand image, Conceptual framework, Antecedents, Moderators, Outcomes, Bangladesh

\section{Introduction}

Conceptual framework of brand image is a combination of antecedents, moderators and outcomes that create differential effects on customer response to the marketing of a brand. Considering the importance of brand image, since last decade 
organizations are engaged to construct the conceptual framework of brand image and enhance sweet blow into customers mind. The conceptual framework indicates a combination of antecedents, moderators and outcomes of brand image. Actually, antecedents, moderators and outcomes are latent variables of brand image whose task to build and hold brand image into customers mind for a long period of time. In this regard, the conceptual framework of brand image bears great significance into today's modern marketing environment. Moreover, the conceptual framework of brand image is one of the essential blocks of customer-based brand equity that underlies as perceptions about a brand which reflected by the brand associations apprehended in customer's memory (Keller, 1998). Hence, it is acknowledged that the conceptual framework of brand image plays an important role as antecedents, moderators and outcomes of brand image that assists organizations and their brands to keep touch within customers' memory for a long period of time.

With this background, this paper we attempt to present a conceptual framework of brand image. We have discussed a conceptual framework that includes brand awareness, brand association, brand superiority, brand affection, brand resonance, corporate social responsibility, tourism management, entertainment, brand familiarity, customer satisfaction, brand trust and attitudinal loyalty that is based on a comprehensive review of the existing literatures and a case study of very prominent hotel brand in Bangladesh. In an attempt to discuss the managerial implications of the conceptual framework, a scenario based on a case study is presented in this paper.

\section{What is Brand Image}

Keller (1998) underlies that brand image has long been recognized as an important concept in marketing and although marketers have not always agreed about how to measure it, one generally accepted view is that brand image is consumers' perceptions about a brand, as reflected by the brand associations held in consumer memory. Keller (2008) mentions in that creating a positive brand image takes marketing programmes that link strong, favorable and unique associations to the brand in memory. Customers are able to form brand associations in a variety of ways other than marketing activities: from direct experience; through information from other commercial or nonpartisan sources. As such, the brand image can be considered as the key concept between the brand and the brand equity based on customer. Moreover, in developing strong brand image through organizations that assist customers to build strong mindset about brand (Katke, 2007).

In this perspective, it can be suggested that by establishing brand image the effect of brand image will build as well as sustain for a long period of time in customers mind. As a result, brand image makes essential impact to explore the effect of conceptual framework of brand image including brand awareness, brand association, brand superiority, brand affection, brand resonance, corporate social responsibility, tourism management, entertainment, brand familiarity, customer satisfaction, brand trust and attitudinal loyalty.

\section{A Conceptual Framework of Brand Image}

Based on literature review, the conceptual framework that explain the antecedents, moderators and outcomes of brand image in a competitive market, known as conceptual framework of brand image. The twelve elements of this framework that includes brand awareness, brand association, brand superiority, brand affection, brand resonance, corporate social responsibility, tourism management, entertainment, brand familiarity, customer satisfaction, brand trust and attitudinal loyalty of the brand are discussed below.

\subsection{Brand Awareness}

According to Keller (1998 and 2008), brand awareness underlies brand recognition and recall performance. Both components are playing active role to build brand image. Moreover, brand awareness creates pressure to increase brand image. So brand awareness is the first step by which customers aware about a brand as well as organization and builds strong associations in the mind of customers. Indeed, brand awareness is the first antecedent of proposed conceptual framework of brand image.

\subsection{Brand Association}

Brand associations are helpful tool for marketers. By using brand associations, marketers differentiate their brands and make a strong position not only customers mind but also into competitive marketplace. According to Aaker (1991), brand associations build and create positive attitudes and feelings towards brands in the mind of customers that enhance brand image. Moreover, brand association is the second antecedent of proposed conceptual framework of brand image. 


\subsection{Brand Superiority}

According to Keller (2009), brand superiority directly communicates with customer evaluation process. With the help of evaluation process, customers generate perceptions in their mind towards brands. In this regard, brand superiority can play an important role to generate positive perceptions about brands in the mind of customers. Moreover, brand superiority along with positive perceptions about brands enhance brand image. Indeed, brand superiority is the third antecedent of proposed conceptual framework of brand image.

\subsection{Brand Affection}

For affection, emotions can play a vital role and create great impact into customer behavior. On the other hand, in a modern consumer attitude model, emotions make relationship between cognitive evaluations and behavioral intentions (Bagozzi, 1992). Within emotional perspective, customers will increase their affection level about brands. Moreover, the affection level positively contributes in perception level. In this regard, affection along with perception enhances brand image, and brand affection is the fourth antecedent of proposed conceptual framework of brand image.

\subsection{Brand Resonance}

Brand resonance underlies final relationship with those customers who are affected by affection (Keller, 2003). With the help of brand resonance, organizations create strong brand loyalty. Moreover, brand resonance describes how to build strong loyal relationships with customers. In this regard, along with the loyalty, brand resonance which is the fifth antecedent enhances brand image for organizations as well as brands.

\subsection{Corporate Social Responsibility}

Nowadays, modern marketing realizes the significance of corporate social responsibility and its impact on brand image. The contribution of corporate social responsibility not only impact on brand image but also encompasses societal wellbeing (Murali Raman et al., 2012). Indeed, to win brand resonance in today's markets, corporate social responsibility has become a useful tool that enhance brand image. Meanwhile, corporate social responsibility is the sixth as well as final antecedent of the proposed conceptual framework of brand image.

\subsection{Tourism Management}

The term tourism comes from different perspectives like economic, managerial, marketing, social, environmental and so on (Rashidul, 1988). Tourism can be segmented into different categories. They would contain holiday travel, visiting friends and relatives (VFR), business travel, health treatment, shopping, conference, incentive travel, official mission, education, sport and others travel (Malaysia Tourism Promotion Board, 2004).According to International Association of Scientific Experts in Tourism (2001), Tourism is the combination of phenomena as well as relationships occurring from the travel and focus on non-residents whose intention do not lead to permanent resident and are not involved with any earning activity. In this context, tourism business is managed by different set of activities where need proper management system. Thus, tourism and management are closely interrelated to each other. In this regard, along with antecedents of brand image which moderated by the degree of tourism management that enhances brand image for organizations as well as brands.

\subsection{Entertainment}

From psychological and sociological point of view, entertainment and recreation services can play a significant role for the quality of tourism product (Vogt and Fesenmeier 1995; Weiermair and Fuchs 1999). On the other hand, from marketing point of view, entertainment as well as recreation services can also perform an important role for tourism product. Basically, Tourism is acknowledged by a service industry as well as entertainment industry (Barlow and Maul 2000). According to Middleton (1997), tourism product underlies into destination attraction, service facilities, accessibility to the destination, the images people have in mind and the price- the total costs of travel, accommodation and participation in several activities. Thus, tourists spend their time of "happiness" within entertainment industry. In this perspective, along with antecedents of brand image which moderated by the degree of entertainment that enhances brand image for organizations as well as brands. The following figure (Figure1: Conceptual Framework of Brand Image) shows the plausible antecedents, moderators and outcomes of brand image. 


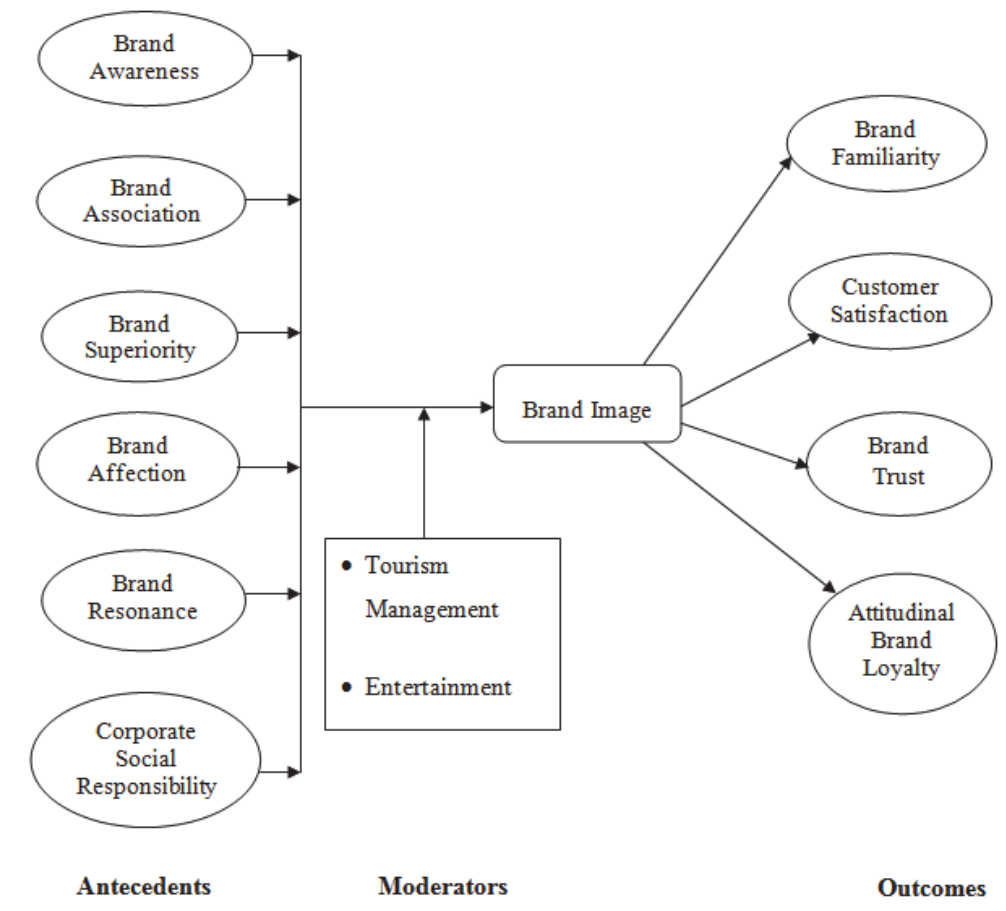

Figure1: A Conceptual Framework of Brand Image

\subsection{Brand Familiarity}

In above figure (Figure1), brand familiarity is the first outcome of the proposed conceptual framework of brand image. Brand familiarity defined as a customer's degree of knowledge connecting a brand through his or her direct and indirect experiences with the brand. Familiarity is being identical with knowledge and reflects on experiences to be the key contributor of brand (Cerjak et al., 2010). In this regard, for sustaining brand image, brand familiarity can play an essential role and enhance positive knowledge with experiences in customers mind.

\subsection{Customer Satisfaction}

Customer satisfaction is the second outcome of the proposed conceptual framework of brand image. Rai (2013) defined customer satisfaction as a buyer's emotional or cognitive response post subjective assessment and comparison of prepurchase expectations and actual performance subsequent to the consumption of the product or service, meanwhile evaluating the costs incurred and benefits reaped in a specific purchase even or over time in course of transacting with an organization. Therefore, customer satisfaction can be defined by an overall satisfaction towards a certain brand based on total cumulative experiences in the mind of customers.

\subsection{Brand Trust}

Brand trust is the third outcome of the proposed conceptual framework of brand image. Trust is like a tie that occurs with customers. With the help of trust, customers bond those who are trustable. In this regard, organizations build a strong emotional bond where trust can play an active role (Mckinney, 2013). According to Mckinney (2013), trust is a combination of credibility, care and congruency. All three components of trust can help to sustain brand image for a long period of time in the mind of customers.

\subsection{Attitudinal Loyalty}

Attitudinal loyalty is the fourth as well as last outcome of the proposed conceptual framework of brand image. Rai and Srivastava (2012) illustrated that a customer can express his degree of loyalty towards a service provider by either displaying a positive attitude or indulging in favourable actions or making conscious evaluations and finding a particular service worth sticking to. Indeed, attitudinal loyalty depends on customer's preference of emotional commitment towards a brand. 


\section{Case Study}

A case study of one Bangladeshi brand hotel was undertaken to explain the approach of conceptual framework of brand image (antecedents, moderators and outcomes). The action points suggested through this case study reinforced the proposed conceptual framework of brand image that act as combination of antecedents, moderators and outcomes of brand image where all elements of suggested framework play as brand image antecedents, moderators and outcomes of brands of hotels.

\section{AG Residence and Boutique Hotel}

AG Residence, the truly, international standard, boutique style, small, luxury hotel in capital city Dhaka at Bangladesh, which has a very high degree of personalized service is owned and managed by a Sri Lanka based BOI (Board Of Investment) company in Dhaka. AG is the only hotel in Bangladesh to be certified with ISO 2000 and HACCP. AG hotel started their activities from January-2000 and since then it has been running with good reputation as well as customer satisfaction. At starting it was managed by Confifi hotel Chain and now it is operated by owner STS (Shanta, Tropica and Sepal) Group. The STS Group also running several business enterprises including Apollo Hospital Dhaka, ISD School, DPS School, Shanta Garments, LonkaBangla Finance etc. AG hotel is conveniently located beside airport road as well as the diplomatic zone at Banani leading to the main city, and adjacent to the diplomatic enclave and upcoming blue chip commercial hub of Baridhara, Gulshan \& Banani, only $7 \mathrm{~km}$ from the main international airport. The hotel is comprising 66 rooms and suites including all rooms feature king, queen or twin size beds, large work areas with High-Speed Internet, twenty four hours air-conditioning service, in-room safe, mini bar, tea/coffee making facilities and ironing facilities. AG hotel is doing regular sales visit to the different organizations (RMG, FMCG, MEDIA, MEDICAL COLLEGE, HOSPITALS, NGO, different AID organizations such as UNAID, German AID, USAID etc.). The hotel management maintaining a very good relation with the media sectors especially the print media. They are using the integrated marketing tools in their marketing strategy and business expansion. They distribute Eid festival Greetings Card, New Year and Christmas Greetings Card. They also distribute their special Cake \& gift hampers to their most valuable and big clients time to time. AG hotel provides different services for the consumers. In general, inside each room they provide air condition, DVD player, television with cable, mini bar, free newspaper, hairdryer, outlet adapters, turndown service, iron with ironing board, smoke detectors and sprinklers in rooms. As room service, they also provide elevators, executive level corridor, ice machine, 24 hour security, phone service etc. Outside the rooms they provide outdoor pool, fitness center, gym, Jacuzzi, Sauna, Steam bath, business center, laundry service, shoe polishing service, concierge desk, wake-up service, meeting/banquet facilities, car rental desk, boutiques, conference facilities, currency exchange, outside catering, accessible facilities for wheel chair access etc. Overall, the AG hotel is a three star and international standard boutique hotel. The main concept of boutique hotel is personalized service. In this regard, the hotel is providing their best support to make their consumers happy and satisfied. For example, if one consumer wants to eat less spicy food their kitchen people make a note and try to make the food according the consumer choice. The location of AG hotel is in a good diplomatic area and the environment is very calm and quiet. The hotel cost is reasonable according to the services. The hotel also does outside catering which is one of their specialties. Adding another feather in their cap, AG hotel was awarded with the "Certificate of Excellence" for year 2013 by Trip Advisor. This prestigious award, which places organizations in the top-performing $10 \%$ of all businesses worldwide on Trip Advisor, is given to businesses that consistently earn high ratings from Trip Advisor travelers. Couple of months ago, Trip Advisor placed AG, the best hotel in terms of guest reviews in Bangladesh and now has been recognized amongst the best globally, which amply proves beyond doubt AG has earned the top slot amongst the best in the world from its own patrons. In fact, consumers are fall in love to AG hotel because they maintain a good relationship between their hotel customers and their patrons those are providing or try to provide the link that assist their business operations. They are highly concern about customer satisfaction. They maintain a customer comments sheet and if any complaint is there they will try to remove with top priority basis. AG has suggestion box where customers as well as employees can drop their suggestions with written format. After a time being AG hotel will organize corporate dinner party, cocktails party, BBQ party where most of the hosts are invited from different organizations. AG hotel practices good relations with diplomats, Embassy and High Commission. Moreover, AG hotel tries to provide extra services which are out of customer's expectation. For example, one customer he or she is staying with them for four days during that time his/her birthday may be occurred. Suddenly they will arrange a surprise birthday party only honor of his or her honorary. Furthermore, AG has adopted corporate social responsibility as a part of their mission. They have made corporate social responsibility one of the important principles of their business. In the context of corporate social responsibility, AG hotel provides good food like Chicken 
Briany every Saturday of a week for 150 persons to missionary of charity at Islampur. They also provide Chicken Briany every $18^{\text {th }}$ day for 175 persons, $20^{\text {th }}$ day for 100 persons, $27^{\text {th }}$ day for 100 persons and $31^{\text {st }}$ day for 100 persons of a month at different places those are Botomoly Orphanage at Farmget, missionary of charity at Tejgaon, Jagoroni Jute Holicross at Tejgaon, road side people at several areas of Dhaka city and Ashkona Orphanage Centre. On the other hand, AG provides services to tourist in terms of enjoyment as well as relaxation that include destination attractions, hotel facilities, accessibility, image and price. For example, they provide tourist attractions on the Crescent Lake in Dhaka at Bangladesh. Moreover, they also provide heritage attraction on the Lalbagh Fort and the Ahsan Manzil in Dhaka at Bangladesh. Additionally, they concern about the entertainment services to tourist in terms of enjoyment as well as relaxation that include evening cultural entertainment, serving quality of food in restaurant, shopping conveniences and beautiful outside location for entertainment. Hence, they provide play ground, gym, swimming pool and adult game zone for entertainment to tourists (customers). AG hotel is associated with the popular name of STS (Shanta, Tropica and Sepal) Group. The name itself has earned a lot of reputation from the market with their several business enterprises including Apollo Hospital Dhaka, ISD School, DPS School, Shanta Garments, LonkaBangla Finance etc. AG hotel serves not only staff training and medical awareness programs twice a month for its staff members but also arranges awareness programs for AG's customers and tries to educate them on several areas that are concerning issue to the development of hospitality industry. On the other hand, STS Group is associated with several services such as hospitality, heath care, education and garments those are well-known to customers and simultaneously customers are highly experienced about STS Group at Bangladesh. The top priority of AG hotel is quality and service. The hotel never compromise with quality at any cost and they strive to provide their guests and clients with the best service at their level best. Additionally, Customer satisfaction is their main goal. They strictly maintain a standard for which customers always keep with them. They arrange surveys and monitor a track on customer feedback forms and also take initiatives where is needed for better performance and keep touch with customers. AG hotel wants their customers feel a hotel like a home, both in the comfort and safety perspective. AG hotel is fully secured with CC cameras on all floors with emergency support and they maintain a good level of trust with their customers based on commitment and co-operation. In this regard, customers are faithful to AG hotel. Due to quality services within hospitality industry, AG hotel becomes a trustworthy brand within hotel sector. In these circumstances, they create a space into customers' mind and customers become a loyal not only behavioral perspective but also attitudinal perspective. All are incurred by their actives regarding quality services, commitment and enthusiastic co-operation towards customers and also positive performances within hospitality industry at service sector of Bangladesh. The following table (Table1: The Antecedents, Moderators and Outcomes of Brand Image) represents the conceptual framework of brand image of AG residence and boutique hotel.

Table1: The Antecedents, Moderators and Outcomes of Brand Image

\begin{tabular}{|c|c|}
\hline \multicolumn{2}{|l|}{ Brand Image } \\
\hline Antecedents & AG residence and boutique hotel \\
\hline Awareness & $\begin{array}{l}\text { AG residence and boutique hotel is doing regular sales visit to the different organizations (RMG, FMCG, MEDIA, } \\
\text { MEDICAL COLLEGE, HOSPITALS, NGO, different AID organizations such as UNAID, German AID, USAID etc.). }\end{array}$ \\
\hline Association & $\begin{array}{l}\text { AG residence and boutique hotel provides different services for consumers. In general, inside the rooms they provide air } \\
\text { condition, DVD player, television with cable, mini bar, free newspaper, hairdryer, outlet adapters, turndown service, iron } \\
\text { with ironing board, smoke detectors, sprinklers, elevators, executive level corridor, ice machine, } 24 \text { hour security, phone } \\
\text { service etc. Outside the rooms they provide outdoor pool, fitness center, gym, Jacuzzi, Sauna, steam bath, business } \\
\text { center, laundry service, shoe polishing service, concierge desk, wake-up service, multilingual, meeting/banquet facilities, } \\
\text { car rental desk, boutiques, conference facilities etc. In dinning, they provide several buffet menus. }\end{array}$ \\
\hline Superiority & $\begin{array}{l}\text { AG hotel is a three star and international standard boutique hotel. The main concept of boutique hotel is personalized } \\
\text { services. They are providing their best support to make their consumers happy and satisfied. For example, if one } \\
\text { consumer wants to eat less spicy food their kitchen people make a note and try to make a food according a consumer } \\
\text { choice. The location of AG hotel is in a good diplomatic area and the environment is very calm and quiet. The hotel cost } \\
\text { is reasonable according to the services. They also do outside catering which is one of their specialties. Adding another } \\
\text { feather in their cap, AG hotel was awarded with the "Certificate of Excellence" for year } 2013 \text { by Trip Advisor. }\end{array}$ \\
\hline Affection & $\begin{array}{l}\text { In fact, consumers are fall in love to AG hotel because they are highly concern about customer satisfaction. They } \\
\text { maintain a customer comments sheet and if any complaint is there, they will try to remove with top priority basis. AG } \\
\text { hotel tries to provide extra services which are out of customer's expectation. For example, one customer he or she is } \\
\text { staying with them for four days during that time his/her birthday may be occurred. Suddenly they will arrange a surprise } \\
\text { birthday party only honor of his or her honorary. }\end{array}$ \\
\hline Resonance & $\begin{array}{l}\text { AG hotel practices good relations with diplomats, Embassy and High Commission. They maintain a good relationship } \\
\text { between their hotel customers and their patrons those are providing or try to provide the link that assist their business } \\
\text { operations. Moreover, AG hotel will organize corporate dinner party, cocktails party, BBQ party where most of the hosts } \\
\text { are invited from different organizations. }\end{array}$ \\
\hline
\end{tabular}




\begin{tabular}{|c|c|}
\hline $\begin{array}{l}\text { Corporate } \\
\text { Social } \\
\text { Responsibility }\end{array}$ & $\begin{array}{l}\text { AG has adopted corporate social responsibility as a part of their mission. In the context of corporate social responsibility, } \\
\text { AG hotel provides Chicken Briany every } 18^{\text {th }} \text { day for } 175 \text { persons, } 20^{\text {th }} \text { day for } 100 \text { persons, } 27^{\text {th }} \text { day for } 100 \text { persons and } \\
31^{\text {st }} \text { day for } 100 \text { persons of a month at different places those are Botomoly Orphanage at Farmget, missionary of charity } \\
\text { at Tejgaon, Jagoroni Jute Holicross at Tejgaon and road side people at several areas of Dhaka city. }\end{array}$ \\
\hline Moderators & AG residence and boutique hotel \\
\hline $\begin{array}{l}\text { Tourism } \\
\text { Management }\end{array}$ & $\begin{array}{l}\text { AG provides services to tourist in terms of enjoyment as well as relaxation that include destination attractions, hotel } \\
\text { facilities, accessibility, image and price. For example, they provide tourist attractions on the Crescent Lake in Dhaka at } \\
\text { Bangladesh. Moreover, they also provide heritage attraction on the Lalbagh Fort and the Ahsan Manzil in Dhaka at } \\
\text { Bangladesh. These facilities of AG hotel create strong brand image into the mind of customers (tourists). }\end{array}$ \\
\hline Entertainment & $\begin{array}{l}\text { AG concerns about the entertainment services to tourist in terms of enjoyment as well as relaxation that include evening } \\
\text { cultural entertainment, serving quality of food in restaurant, shopping conveniences and beautiful outside location for } \\
\text { entertainment. Hence, they provide play ground, gym, swimming pool and adult game zone for entertainment to tourists } \\
\text { (customers). All are incurred by their actives regarding quality services, commitment and enthusiastic co-operation } \\
\text { towards customers (tourists) and also positive performances along with strong brand image within hospitality industry at } \\
\text { service sector of Bangladesh. }\end{array}$ \\
\hline Outcomes & AG residence and boutique hotel \\
\hline Familiarity & $\begin{array}{l}\text { AG hotel is associated with the popular name of the STS (Shanta, Tropica and Sepal) Group. The name itself has } \\
\text { earned a lot of reputation from the market with their several business enterprises including Apollo Hospital Dhaka, ISD } \\
\text { School, DPS School, Shanta Garments, LonkaBangla Finance etc. AG hotel serves not only staff training and medical } \\
\text { awareness programs twice a month for its staff members but also arranges awareness programs for AG's customers and } \\
\text { tries to educate them on several areas that are concerning issue to the development of hospitality industry. On the other } \\
\text { hand, STS Group is associated with several services such as hospitality, heath care, education and garments those are } \\
\text { well-known to customers and simultaneously customers are highly experienced about STS Group at Bangladesh. }\end{array}$ \\
\hline Satisfaction & $\begin{array}{l}\text { The top priority of AG hotel is quality and service. The hotel never compromise with quality at any cost and they strive to } \\
\text { provide their guests and clients with the best service at their level best. Additionally, they provide discount card, Eid } \\
\text { festival greetings Card, New Year and Christmas greetings card. They also distribute their special Cake \& gift hampers to } \\
\text { their most valuable and big clients time to time and maintain customer relationship. Customer satisfaction is their main } \\
\text { goal. They strictly maintain a standard for which customers always keep with them. They arrange surveys and monitor a } \\
\text { track on customer feedback forms and also take initiatives where is needed for better performance and keep touch with } \\
\text { customers. }\end{array}$ \\
\hline Trust & $\begin{array}{l}\text { AG hotel wants that their customers feel a hotel like a home, both in the comfort and safety perspective. AG hotel is fully } \\
\text { secured with CC cameras on all floors with emergency support and they maintain a good level of trust with their } \\
\text { customers based on commitment and co-operation. In this regard, customers are faithful to AG hotel. }\end{array}$ \\
\hline $\begin{array}{l}\text { Attitudinal } \\
\text { Loyalty }\end{array}$ & $\begin{array}{l}\text { Due to quality services within hospitality industry, AG hotel becomes a trustworthy brand within hotel sector. In these } \\
\text { circumstances, they create a space into customers' mind and customers become a loyal not only behavioral perspective } \\
\text { but also attitudinal perspective. All are incurred by their actives regarding quality services, commitment and enthusiastic } \\
\text { co-operation towards customers and also positive performances within hospitality industry at service sector of } \\
\text { Bangladesh. }\end{array}$ \\
\hline
\end{tabular}

\section{Discussion}

The suggested conceptual framework of brand image provides possible antecedents, moderators and outcomes of brand image to marketers. Along with possible antecedents, moderators and outcomes marketers make a strong brand image as well as customer relationship for a long period of time. Regarding a strong brand image and customer relationship, marketers take competitive advantages from target markets. Indeed, nowadays modern marketing and market is challenging for marketers to build brand image and sustain customer relationship for a long period of time. In this regard, this proposed framework should assist marketers to build brand image and sustain as well as maintain customer relationship for a long period of time. On the other hand, marketers also want to create strong resonance along with corporate social responsibility and loyalty with customers where the degree of tourism management and entertainment play a significant role. In this perspective, this suggested framework will assist marketers to create strong resonance along with corporate social responsibility and customer loyalty that is significantly moderated by the degree of tourism management and entertainment. The marketers will be able to do it from customer familiarity to a brand along with customer satisfaction, trust and attitudinal loyalty. Thus, this suggested framework should influence marketers to construct strong brand resonance along with corporate social responsibility and loyalty with the help of degree of tourism management and entertainment as well as sustainable brand image with the help of possible conceptual framework of brand image. We assume that with the help of this proposed framework, marketers will increase brand image and customers' knowledge level about an organization and its brands. We further assume that this framework will be highly acknowledged by customer-based brand equity. This is so as framework awareness, associations, superiority, affection, resonance, corporate social responsibility, tourism management, entertainment, familiarity, satisfaction, trust and attitudinal loyalty always knock to customer's engagement about a brand. 
Finally, this proposed framework should not only provide theoretical authentication that supports the significance of antecedents, moderators and outcomes of brand image but also will present an accomplishment process which will show how the antecedents, moderators and outcomes of brand image can affect an organization's market performance in the marketplace. Therefore, we believe this proposed framework provides the much needed indication that high level of brand awareness, brand association, brand superiority, brand affection, brand resonance, corporate social responsibility, tourism management, entertainment, brand familiarity, customer satisfaction, brand trust and attitudinal loyalty increase the probability of the effect of brand image.

\section{Conclusion}

This paper discusses the conceptual framework of brand image that represents the antecedents, moderators and outcomes of brand image. This paper also presents a case study and discussed it based on the review of pertinent literatures. As discussed in this conceptual paper, brand image creates competitive advantage of product in the marketplace and enhance overall organizational goodwill, trust and credibility. We suggest that the antecedents, moderators and outcomes of brand image dimensions in the context of suggested conceptual framework of brand image would be a potential for building a strong brand in the modern marketing environment because the antecedents, moderators and outcomes of brand image can offer valuable managerial implications that will help the brand managers. Many of the ideas expressed in this proposed conceptual framework will provide a more comprehensive picture of how organizations can create brand image and sustain brand image for a brand. Moreover, we believe that with the help of this proposed conceptual framework, organizations will be able to build brand image and make customer relationship into a competitive marketplace. Overall, we suggest that the twelve variables proposed in conceptual framework of brand image namely, brand awareness, brand association, brand superiority, brand affection, brand resonance, corporate social responsibility, tourism management, entertainment, familiarity of the brand, customer satisfaction of the brand, trust on the brand and attitudinal loyalty of the brand can enable organizations to create brand image and sustain brand image for a long period of time in a competitive market.

\section{References}

Aaker, D. A. (1991). Managing Brand Equity. Ontario, The Free Press, pp.7, 8, 39, 61, 110.

Bagozzi, R.P. (1992). The self-regulation of attitudes, intentions, and behaviours. Social Psychology Quarterly, 55, pp. 178-184.

Barlow, J., \& Maul, D. (2000). Emotional value: Creating strong bonds with your customers. 1st Ed. Berrett-Koehler Publishers. ISBN: 978-160509-724-4, pp: 15, 58, 111, 121, 223, 244.

Cerjak, M., Haas, R. \& Kovacic, D. (2010). Brand familiarity and tasting in conjoint analysis: an experimental study with Croatian beer consumers. British Food Journal, 112 (6), pp. 561-579.

International Association of Scientific Experts in Tourism (2001). Tourism growth and global competition: 51th congress, 2001, Malta. P. Keller (Ed.). Éd. AIEST. http://www.hospitalitynet.org/organization/17010400.html (Accessed on July 25, 2014).

Katke, K. (2007). The Impact of television advertising on child health and family spending-A Case Study, pp. 55-76.

Keller, K. L. (1998). Strategic Brand Management: Building, Measuring, and Managing Brand Equity. Upper Saddle River, NJ: Prentice Hall, pp.93.

Keller, K. L. (2003). Brand synthesis: The multidimensionality of brand knowledge. Journal of consumer research, 29(4), pp. 595-600.

Keller, K.L. (2008). Strategic brand management: building, measuring, and managing brand equity (3rd ed.). New Jersey, N.J.: Prentice-Hall, pp. 5, 51.

Keller, K.L. (2009). Building strong brands in a modern marketing communications environment. Journal of Marketing Communications, 15(2-3), pp. 139-155.

Malaysia Tourism Promotion Board (2004). Profile of Tourists by Selected Market 2004. Planning and Research Division, Tourism Malaysia, Kuala Lumpur. http://www.tourism.gov.my/en/my (Accessed on July 25, 2014).

Mckinney, M. E., \& Benson, A. (2013). The value of brand trust. Journal of Brand Strategy, 2(1), pp. 76-86.

Middleton, U. (1997). Tourist Product, in: S. Witt \& L. Mutinho (Eds) Tourism Marketing and Management Handbook. ISBN: 0-13-925885-X and 013-923384-9, pp: 572-576

Murali Raman, Wayne Lim and Sumitra Nair (2012). The Impact of Corporate Social Responsibility on Consumer Loyalty. Journal of Malaysian Studies, 30(2), pp. 71-93.

Rai, A. K. \& M. Srivastava (2012). "Customer Loyalty Attributes: A Perspective," NMMS Management Review, 22 (October - November), pp. 49 -76.

Rai, A.K. (2013). Customer Relationship Management: Concepts \& Cases, New Delhi: PHI Learning, pp. 105.

Syed Rashidul Hasan (1988). "Tourism prospect in Bangladesh", The Dhaka University Studies, Part-C, Vol. 9, Issue-2, pp: $19-32$. URL:http://scholar.google.com.my/scholar?cluster $=8994110490838939658 \& h l=e n \& a s \_s d t=2005 \&$ sciodt $=0,5$

Vogt, C. A., \& Fesenmaier, D. R. (1995). Tourists and retailers' perceptions of services. Annals of Tourism Research, 22(4): 763-780. DOl: 10.1016/0160-7383(95)00039-9

Weiermair, K., \& Fuchs, M. (1999). Measuring tourist judgment on service quality. Annals of Tourism Research, 26(4): 1004-1021. DOI: 10.1016/S0160-7383(99)00037-7 